\title{
Analysis of Microbiological Contamination in Cultivation and Distribution Stage of Melon
}

\author{
Kyeong-Hun Park, ${ }^{3,4}$ Hye-Jeong Yun', Won-Il Kim, Jun-Won Kang ${ }^{2}$, \\ Patricia D. Millner ${ }^{3}$, Shirley A. Micallef ${ }^{4}$, and Byeong-Seok Kim ${ }^{5}$. \\ Microbial Safety Team, National Academy of Agricultural Science, RDA, Suwon, 441-707, Korea \\ ${ }^{1}$ Experiment Research Institute, National Agricultural Products Quality Management Service, Seoul, 150-804, Korea \\ ${ }^{2}$ Germplasm Resources Lab, USDA-ARS, Beltsville, Maryland, 20705, USA \\ ${ }^{3}$ Environmental Microbial \& Food Safety Lab, USDA-ARS, Beltsville, Maryland, 20705, USA \\ ${ }^{4}$ Department of Plant Science and Landscape Architecture, University of Maryland, CollegePark, Maryland, 20770, USA \\ ${ }^{5}$ Planning\&Coordination Division, National Academy of Agricultural Science, RDA, Suwon, 441-707, Korea
}

(Received: November 15 2013, Accepted: December 2 2013)

The purpose of this study was to evaluate microbial contamination of melons in Korea. A total of 123 samples including melon fruits, leaves, seeds, soils, and inigation water were collected from farms and markets to detect total aerobic bacteria, coliform, Escherichia coli, and pathogenic bacteria such as Bacillus cereus, Listeria monocytogenes, Salmonella spp., and Staphylococcus aureus. Samples were collected from Iksan and Nonsan farms to monitor bacterial levels on pre-market melons. The total aerobic and coliform bacteria on melon cultivation were between 0.43 and $6.65 \log \mathrm{CFU} \mathrm{g}^{-1}$, and 0.67 and $2.91 \log \mathrm{CFU} \mathrm{g}^{-1}$, respectively. Bacillus cereus, a fecal coliform, was detected in soils and melon leaves from Iksan farm at 2.95, 0.73 log CFU

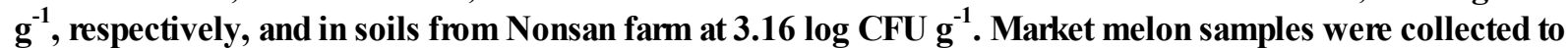
assay bacterial load on melon being sold to consumers. The contamination levels of total aerobic bacteria in agricultural markets, big-box retailers, and traditional markets were $4.82,3.94,3.99 \log \mathrm{CFU} \mathrm{g}^{-1}$, respectively. The numbers of coliform in melon on the markets ranged from 0.09 to $0.49 \mathrm{log} \mathrm{CFU}$ g- 1 . Listeria monocytogenes, Salmonella spp., and Staphylococcus aureus were not detected in any samples. The count of total aerobic bacteria on melon seeds ranged from 0.33 to $3.34 \log \mathrm{CFU} \mathrm{g}^{-1}$. This study found that irrigation water, soil, manure and various farm work activities including post-harvest processes were latent sources of microbial contamination. These results suggest that hygienic management and monitoring of soil, water, and agricultural material should be performed to reduce microbial contamination in melon production.

Key words: Melon, Microbial contamination, Foodborne pathogen, Food safety

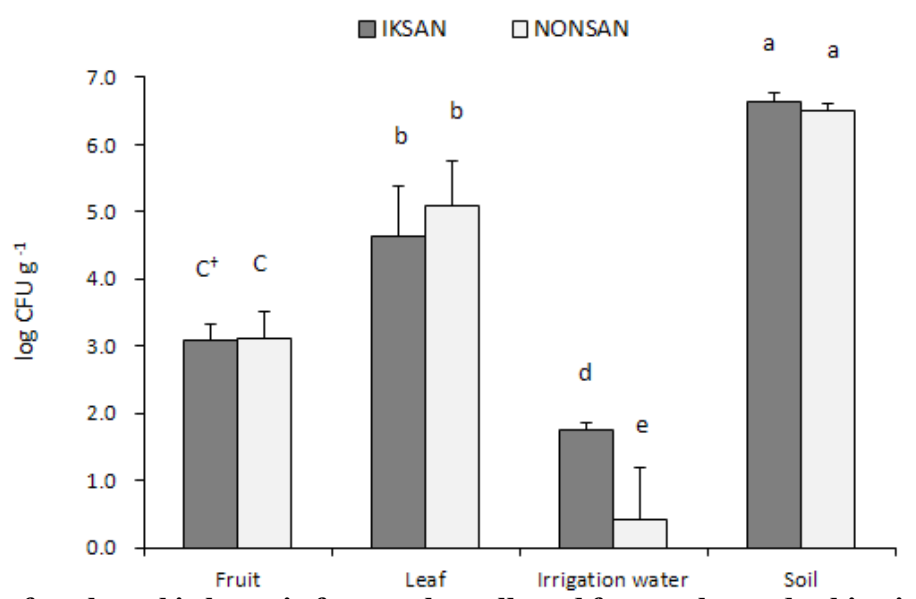

Population of total aerobic bacteria for samples collected from melon and cultivation environment.

\footnotetext{
*Corresponding author : Phone: +82312900152, Fax:+82312900105, E-mail: kim2000@korea.kr

${ }^{\S}$ Acknowledgement: This work was supported by the research grant of Agriculture Science \& Technology Development (Project No. PJ008751) Rural Development Admistration, Republic of Korea.
} 


\section{Introduction}

최근 경제생활 향상과 건강에 대한 관심 증가로 소비자 의 식생활이 변화함에 따라 채소류, 곡류 및 과채류 등 신선 농산물에 대한 소비와 관심이 증가 하고 있다. 멜론은 비타 민 $\mathrm{A}, \mathrm{C}$ 함량과 철분 및 나아신 등 영양분이 풍부하고 맛과 향이 좋아 소비자에게 각광을 받고 있다 (Pitrat et al., 2000; Yong, 2008).

멜론 (Cucumis melo L.)은 열대지방에서 주로 재배되는 박과의 덩굴성 한해살이 작물로 원산지는 아프리카이고 중 앙아시아와 북유럽 및 인도를 걸쳐 전 세계적으로 재배되고 있다 (Kerje and Grum, 2000). 과실표면의 그물모양 유무 에 따라 네트멜론과 무네트 멜론으로 구분되며, 국내에서 대부분이 시설 내에서 토경재배의 형태로 연중 재배되고 있 다 (Lee, 2005; Yi et al., 2004). 1970년 말에 국내에서 교 배종 멜론이 재배되기 시작해, 소규모로 재배되다가 2000 년도에 재배면적이 약 $700 \mathrm{ha}$ 로 증가하였다. 최근 들어 소 비자의 구매 욕구 증가로 인한 소비확대와 가격 상승 등으 로 2007년 이후로는 재배면적이 $1,600 \mathrm{ha}$ 를 넘었으며 2009 년 생산량은 약 5 만톤 정도로 재배면적과 생산량이 증가하 고 있다 (Hong, 2009).

미국에서 1996에서 2008년 까지 보고된 82건의 신선농산 물 식중독 사고 중 13 건 (15.9\%)가 멜론이 원인으로 확인되 었으며 농산물 재배과정 중 E. coli O157:H7, Salmonella spp., Listeria monocytogenes 등과 같은 병원성 미생물 오 염에 의한 식중독 사고 발생이 증가하고 있다 (CDC, 2013). 병원성 미생물의 오염경로는 관개수, 토양, 잔재물 과 농업 활동 등으로 알려져 있으며 농산물의 재배단계부터 철저한 안전관리가 필요하지만 (Painter et al., 2013), 국내에서 관 련연구는 부족한 실정이다.

국내에서 멜론에 관한 연구는 품질향상 (Kim et al., 2011a; Cha et al., 2013), 수확 후 관리 (Choi et al., 2001; Oh et al., 2011), 재배생리에 관한 연구 (Cha et al., 2006; Zhang, et al., 2006) 등이 진행되고 있으나, 멜론 생산단계에서 생 물적 위해요소 및 안전성에 관한 연구는 매우 미흡하다.

따라서, 본 연구는 토경재배를 하는 무네트 멜론을 대상 으로 생산단계에서 유통단계에 따른 미생물 오염도를 평가 하기 위하여 멜론종자, 토양 및 관개수, 과실 과 잎을 채집 하였다. 채집한 시료에서 총호기성균, 대장균군 과 대장균, Bacillus cereus, Listeria monocytogenes, Staphylococcus areus 등 병원성 미생물의 오염정도를 조사하였으며, 이를 통해 멜론의 생물적 위해요소 및 안전생산을 위한 기초자료 로 활용하고자 하였다.

\section{Materials and Methods}

시료채집 재배과정 중 토양 및 관개수의 생물적 위해 요소 분석을 위한 시료는 2012년 충남 논산과 전북 익산에 위치한 멜론 경작지 각각 3 곳에서 채집하였다. 토양 시료 는 유해미생물에 대한 오염 가능성이 높은 표토 $10 \mathrm{~cm}$ 내외 의 토양을 대상으로 각각의 장소에서 10지점 이상으로 채집 하여 혼합하여 사용하였으며, 관개수는 $2 \mathrm{~L}$ 멸균 채수병을 이용하여 수집하였다. 멜론은 수확기에 과실과 잎 부위로 구 분하여 채집하였으며, 멸균팩에 담아 냉장상자로 운반하여 냉 장고에 보관하면서 1 일 이내에 실험에 사용하였다 (Table 1).

유통단계 멜론의 미생물 분포에 대한 조사를 하기 위하 여, 멜론은 경기도 수원시 소재의 대형마트, 농산물시장, 재 래시장에서 각각 3 곳의 장소에서 시료를 구입하여, 냉장상 태로 운반하였으며, 운반즉시 바로 실험을 수행하였다.

시판중인 멜론 종자의 미생물 오염도를 조사하기 위하여, 경기도 수원시에 소재하는 종묘사로 부터 네트가 있는 멜론 종자와 네트가 없는 멜론 종자를 구입하여 실험에 사용하였다.

시료 전처리 수집한 시료 중 과실은 멸균한 칼을 이용 하여 $25 \mathrm{~g}$ 을 정량하였고, 토양 시료와 관개용수는 각각 $25 \mathrm{~g}$ 과, $25 \mathrm{~mL}$ 을 정량하였으며, $0.1 \%$ 펩톤수 $225 \mathrm{~mL}$ 를 넣어 스

Table 1. Samples used in this study for investigation of microorganism contamination.

\begin{tabular}{cccc}
\hline \hline Stage & Sample & Unit of sample & No. of sample \\
\hline \multirow{3}{*}{ Cultivation } & Leaf & $5 \mathrm{~g}$ & 18 \\
& Fruit & $25 \mathrm{~g}$ & 18 \\
& Soil & $25 \mathrm{~g}$ & 18 \\
& Irrigation water & $25 \mathrm{ml}$ & 6 \\
& Agricultural market & $25 \mathrm{~g}$ & 9 \\
& Big-box retailer & $25 \mathrm{~g}$ & 9 \\
& Traditional market & $25 \mathrm{~g}$ & 9 \\
& Non-net & $2 \mathrm{~g}$ & 18 \\
\hline & Net & $2 \mathrm{~g}$ & 18 \\
\hline
\end{tabular}


토마커 (Interscience, France)로 $250 \mathrm{rpm}$ 에서 2분간 균질 화하여 제조한 액을 10 배 희석액으로 간주하고 미생물 분석 을 위한 시험용액으로 사용하였다. 멜론 종자는 각각 $2 \mathrm{~g}$ 을 정량하여 $0.1 \%$ 펩톤수 $18 \mathrm{~mL}$ 가 담긴 멸균백에 담아 스토마 커를 이용하여 2 분간 균질화 하였으며, 멜론 잎은 $5 \mathrm{~g}$ 을 채 집하여 $0.1 \%$ 펩톤수 $45 \mathrm{ml}$ 을 혼합하여 2 분간 균질화 한 다 음, $9 \mathrm{ml}$ 의 $0.1 \%$ 펩톤수를 이용하여 10 배씩 연속 희석하여 사용하였다.

총호기성균 분석 전 처리된 시험용액 $1 \mathrm{~mL}$ 를 $0.1 \%$ 펩 톤 수 $9 \mathrm{~mL}$ 을 이용하여 10 배씩 단계적으로 희석하였다. 각 각의 희석된 시료 $1 \mathrm{~mL}$ 는 $3 \mathrm{M}$ Petrifilm ${ }^{\mathrm{TM}}$ aerobic count plate (3M, USA)위에 분주하고 $36 \pm 1^{\circ} \mathrm{C}$ 배양기에 $24 \sim 48$ 시 간 배양 하였으며, petrifilm 위에 형성된 적색 집락을 계수 하였다.

대장균 및 대장균군 분석 시험용액 $1 \mathrm{~mL}$ 를 $0.1 \%$ 펩 톤수 $9 \mathrm{~mL}$ 에 십진 희석하고, 전처리 시험용액 $1 \mathrm{~mL}$ 와 희석 된 시료 $1 \mathrm{~mL}$ 을 $3 \mathrm{M}$ Petrifilm ${ }^{\mathrm{TM}}$ E. coli/coliform plate(3M, $\mathrm{USA}$ )에 $1 \mathrm{~mL}$ 씩 분주하여 $36 \pm 1^{\circ} \mathrm{C}$ 에서 24 48시간 배양 한 후 기포를 수반하는 청색 집락을 대장균 양성으로, 기포를 수반하는 청색집락과 기포를 수반하는 적색 집락을 대장균 군 양성으로 계수하였다.

병원성 미생물 분석 병원성미생물 총 4 종 (B. cereus, L. monocytogenes, Salmonella spp., S. aureus)의 분석은 식품공전에 준하여 실시하였다 (KFDA, 2011). B. cereus의 분석을 위해 전 처리된 시험용액 $1 \mathrm{~mL}$ 을 $0.1 \%$ 펩톤수에 10 배씩 연속 희석하여 Mannitol Egg Yolk Polymyxin Agar (MYP, Oxoid)에 도말한 후 $30^{\circ} \mathrm{C}$ 에서 24 시간 배양하였다. 흰색 또는 분홍색 집락에 lecithinase를 생성하는 혼탁한 환 을 생성하는 집락을 선발하여 TSA에 순수분리 하였으며, 그람염색 및 생화학성특성을 확인하고 Choo 등 (2007)의 방 법에 따라 $\mathrm{PCR}$ 로 최종 확인하였다. S. aureus의 검출을 위 해서 희석액 200 ul을 Baird Parker Agar (BPA, Oxoid)에 분주하고 $37^{\circ} \mathrm{C}$ 에서 $24 \sim 48$ 시간 배양한 다음 검정색에 투명 한 환을 갖는 집락을 계수하였다. 계수한 집락은 TSA에 순 수분리하여 Vicedo와 Aznar (2006)의 방법에 따라 PCR로 최종 동정하였다. Salmonella 검출을 위해 시험용액 $200 \mathrm{ul}$ 를 XLDagar (Oxoid)에 도말한 다음 $37^{\circ} \mathrm{C}$ 에서 24 시간 배양 하였다. 가운데 부분이 검은 붉은 집락을 순수분리 한 후 그 람염색 및 생화학적 특성을 확인하고 Kong 등 (2002)의 방 법에 따라 PCR로 확인하였다. L. monocytogenes 분석을 위 해 각각의 시료를 Listeria enrichment broth (LEB, Oxoid) 에 $1: 9$ 의 비율로 넣어 스토마커에서 $250 \mathrm{rpm}$ 으로 2 분간 균 질화 한 다음 Oxford agar (OA, Oxoid)에 200 ul 씩 도말하
여 $30^{\circ} \mathrm{C}$ 에서 $24 \sim 48$ 시간 배양하였다. 정성분석을 위해 균질 액을 $30^{\circ} \mathrm{C}$ 에서 24 시간 1 차 증균하였다. 1 차 증균액 $0.1 \mathrm{~mL}$ 을 Fraser Listeria broth $10 \mathrm{~mL}$ 에 접종하고 $37^{\circ} \mathrm{C}$ 에서 24 시 간 동안 2 차 증균 배양하였다. 증균배양액 $200 \mathrm{ul}$ 를 Oxford agar에 도말하고 $30^{\circ} \mathrm{C}$ 에서 $24 \sim 48$ 시간 배양하였다. 검은색 환이 있는 갈색집락을 TSA에 순수분리 한 후 그람염색과 생화화적 특성을 확인 하였고, Aznar 와 Alarcon (2003)의 방법에 따라 $\mathrm{PCR}$ 로 최종 확인하였다.

통계분석 모든 실험은 3 회 이상 반복하여 수행하였으 며, 자료는 $\log \mathrm{CFU} \mathrm{g}^{-1}$ 로 환산하였고, SAS프로그램 (ver 9.2) 을 이용하여 일원분산분석을 실시한 후 Duncan's multiple range test를 통해 유의성을 검증하였다.

\section{Results and Discussion}

생산단계에서 미생물오염 정도 멜론 생산단계에서 총호기성균의 오염정도를 조사한 결과는 Fig. 1과 같다. 총 호기성 균은 전북익산과 충남 논산의 위치한 멜론경작지 토 양에서 각각 $6.65,6.50 \mathrm{log} \mathrm{CFU} \mathrm{g}^{-1}$ 로 확인되었으며, 관개 수에서는 각각 $1.74,0.43 \log \mathrm{CFU} \mathrm{g}^{-1}$ 로 검출되었다. 익산 지역에서 멜론 과실과 잎에서 총호기성균이 각각 $3.08,4.65$ $\log \mathrm{CFU} \mathrm{g}^{-1}$ 로 검출되어 논산지역 3.11, 5.08 log $\mathrm{CFU} \mathrm{g}^{-1}$ 보다 적게 검출되었으나 지역 간의 유의한 차이는 확인되지 않았다 $(p<0.05)$. 농산물에서 총호기성균의 검출이 인체에 대한 유해성과의 관계를 직접 언급할 수 없지만, 농식품의 생산 및 유통. 가공 단계에서 위생조건 및 잠재적인 식품 안 전성을 확인할 수 있는 정보로 사용되는 것으로 알려져 있 어 (Kang and Yoon, 2004), 재배단계에서부터 오염을 최소 화 하는 관리방법이 필요하다고 생각된다. Gagliardi 등(2003) 의 연구에서는 생산단계의 멜론 과실 표면에서 총호기성균 이 2.5 3.5 log $\mathrm{CFU} \mathrm{g}$ g 수준으로 오염되어 있었고, 세척

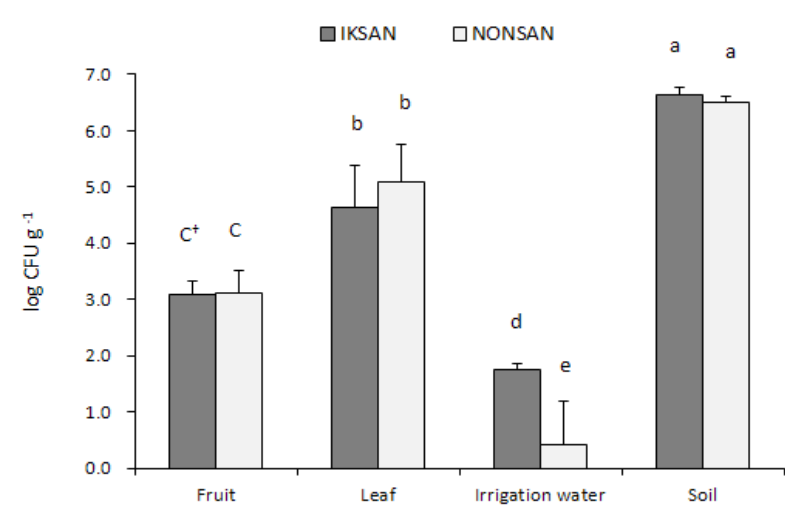

Fig. 1. Population of total aenobic bacteria for samples collected from melon and cultivation environment. ${ }^{\dagger}$ values with different letters within the same column differ significantly $(P<0.05)$. Mean \pm Standard Deviation. 
후에는 4.0 5.0 $\log \mathrm{CFU} \mathrm{g}^{-1}$ 수준으로 검출되었으며, 대장 균군은 수확 후 처리 과정 후 2.6 3.7 log $\mathrm{CFU} \mathrm{g}^{-1}$ 수준으 로 오염되어 있는 것으로 확인되었다. 대장균군은 토양과 물 등 자연환경에 넓게 분포해 있는 세균으로 식품위생상 분변오염의 지표로 활용되고 있다 (Yu et al., 2009). 전북 익산에서 경작지 토양과, 멜론 잎과 과실에서 각각 $2.91,1.48$, $0.67 \log \mathrm{CFU} \mathrm{g}^{-1}$ 로 대장균군이 검출되었고, 논산에서는 토 양과 과실에서 $0.7 \log \mathrm{CFU} \mathrm{g}^{-1}$ 이하로 낮게 검출되었으나 멜론 잎에서 $2.74 \log \mathrm{CFU} \mathrm{g}^{-1}$ 로 비교적 높게 검출되었다 (Table 2). 이러한 결과는 Gagliardi 등 (2003)의 연구결과 와 같이 대장균군이 토양, 관개수 뿐만 아니라 농작업자의 오염된 손이나 경작활동 등 다양한 요인을 통하여 농산물로 오염되기 때문으로 생각된다.

Bacillus cereus는 포자를 형성하는 그람양성균으로 작물 의 근권부위에 있는 토양 속이나, 관개수, 농기구 등 농업환경 및 곡류, 과채류 등에 널리 존재하며, 다른 식품과의 교차오염 을 통해 식중독을 유발하는 것으로 알려져 있다 (Halverson et al., 1993; Jensen et al., 2003). 상추와 생산환경의 미생물 안전성 평가 연구에서 재배토양과 퇴비에서 B. cereus가 3.48, $1.20 \mathrm{log} \mathrm{CFU} \mathrm{g}^{-1}$ 수준으로 검출되었으며 (Kim et al., 2011b), Park 등 (2012)은 당귀 재배 토양에서 B. cereus가 $3.41 \mathrm{log}$ $\mathrm{CFU} \mathrm{g}{ }^{-1}$ 수준으로 검출되었다고 보고하였다. 본 연구에서 도 재배 지역에 상관없이 B. cereus가 토양에서 $3 \log \mathrm{CFU}$ $\mathrm{g}^{-1}$ 내외의 수준으로 검출되었고, 멜론 잎에서 $0.73 \mathrm{log}$ $\mathrm{CFU} \mathrm{g}{ }^{-1}$ 로 검출되었으며, 관개수와 과실에서는 검출되지 않았다.

Salmonella enterica와 같은 병원균은 다양한 멜론 포장 의 토양에서 검출되어 왔으며, 지상부 반점과 껍질에 긁힌 상처 등을 통해 멜론으로 침입할 수 있다 (Gallegos-Robles et al., 2009). L. monocytogens, S. enterica 와 E. coliO157 등 병원성 미생물들은 멜론 재배 토양에서 최소 몇 달에서
수개월 동안 생존이 가능한 것으로 확인되었다 (Suslow et al., 2010). L. monocytogenes는 토양이나 물에서 쉽게 발 견되는 미생물로 멜론 식중독 사고 원인균으로 보고되어 왔 다 (CDC, 2008). 또한, 병원성미생물은 토양개량제 안으로 유입 될 수 있으며 오염된 분변 등을 통해 멜론에 접촉될 경 우 식중독 오염사고를 일으킬 수 있다 (FAO/WHO, 2008).

본 연구에서, 대장균군과 B. cereus 등을 제외한 다른 병 원성 미생물이 검출되지 않아 국내에서 멜론은 비교적 안전 하게 재배되고 있는 것으로 확인되었다. 하지만, 재배과정 중 특히, 수확시기에 병원성미생물에 오염된 토양이나 물에 노출될 경우 멜론에서 식중독 오염 가능성이 존재한다(FDA, 2009). 또한, 상추와 깻잎 등 가식부위가 토양과 가까이 재 배되는 농산물일수록 총호기성균과 병원성미생물 오염도가 높고, 식중독 발생 가능성이 높은 것으로 보고되었다 (Jung et al., 2006; Hong et al., 2012). Ukuku 등 (2012)은 재배 과정 중에 오염된 미생물이 멜론표면에 존재할 경우 멜론과 육으로의 오염 가능성을 확인하였다. 따라서, 멜론 재배단 계에서 플라스틱이나 볏짚 등을 이용한 토양멀칭을 통하여 토양과 지상부와의 접촉을 최소화하고, 관개수를 공급할 경 우 토양이 과실에 묻지 않도록 재배단계에서부터 위생관리 가 중요하다. 또한, 멜론의 생산과정 중 병원성 미생물에 의 해 오염이 되지 않도록 토양, 관개수 및 농자재 안전관리와 같은 농산물우수관리인증의 도입이 필요하다고 생각된다.

유통단계에서 미생물 오염정도 유통단계에서 멜론 의 미생물 오염도를 조사한 결과는 Table 3 에 나타내었다. 국내에서 유통되는 채소류에서 일반적으로 검출되는 총호 기성 균은 3.7 8 $\log \mathrm{CFU} \mathrm{g}{ }^{-1}$ 수준의 넓은 범위로 알려져 있으며 (Bae et al., 2011; Jung et al., 2012), 토양과 먼지 등과 접촉하는 기회가 많을수록 오염도가 높은 것으로 보고 되었다 (Jung et al., 2006). 본 연구에서 총호기성 균은

Table 2. Levels of microbial contamination of samples collected from melon and cultivation environment.

\begin{tabular}{cccccccc}
\hline $\begin{array}{c}\text { Cultivation } \\
\text { area }\end{array}$ & Type & E. coli & Coliform & B. cereus & L. monocytogenes & S. aureus & Salmonella spp. \\
\hline \multirow{4}{*}{ Iksan } & & & & & & \\
& Leaf & N.D. & $1.48 \pm 1.29 \mathrm{ab}^{\dagger}$ & $0.73 \pm 0.64$ & N.D. & N.D. & N.D. \\
& Fruit & N.D. & $0.67 \pm 0.58 \mathrm{~b}$ & N.D. & N.D. & N.D. & N.D. \\
& Soil & N.D. & $2.91 \pm 1.73 \mathrm{a}$ & $2.95 \pm 0.09$ & N.D. & N.D. & N.D. \\
& Irrigation water & N.D. & N.D.c & N.D. & N.D. & N.D. & N.D. \\
& Leaf & N.D. & $2.74 \pm 0.63 \mathrm{a}$ & N.D. & N.D. & N.D. & N.D. \\
Nonsan & Fruit & N.D. & $0.22 \pm 0.39 \mathrm{~b}$ & N.D. & N.D. & N.D. & N.D. \\
& Soil & N.D. & $0.67 \pm 1.15 \mathrm{~b}$ & $3.16 \pm 0.15$ & N.D. & N.D. & N.D. \\
& Irrigation water & N.D. & N.D.c & N.D. & N.D. & N.D. & N.D. \\
\hline
\end{tabular}

\footnotetext{
$\dagger$ Values with different letters within the same column differ significantly $(P<0.05)$. Mean \pm Standard Deviation.

${ }^{\ddagger}$ N.D. : Viable cell was not detected with detection limit at $<1 \log$ CFU $g^{-1}$.
} 
Table 3. Populations of microorganisms in melons collected from different market place.

\begin{tabular}{cccccccc}
\hline \hline Sampling Site & $\begin{array}{c}\text { Total aerobic } \\
\text { bacteria }\end{array}$ & E. coli & Coliform & B. cereus & L. monocytogenes & S. aureus & Salmonella spp. \\
\hline Agricultural market & $4.82 \pm 0.54 \mathrm{a}^{\dagger}$ & N.D. $^{\ddagger}$ & 0.21 & N.D. & N.D. & N.D. & N.D. \\
Big-box retailer & $3.94 \pm 0.42 \mathrm{~b}$ & N.D. & 0.49 & N.D. & N.D. & N.D. & N.D. \\
Traditional market & $3.99 \pm 0.58 \mathrm{~b}$ & N.D. & 0.09 & N.D. & N.D. & N.D. & N.D. \\
\hline
\end{tabular}

${ }^{\dagger}$ Values with different letters within the same column differ significantly $(P<0.05)$. Mean \pm Standard Deviation.

${ }^{*}$ N.D. : Viable cell was not detected with detection limit at $<1 \log \mathrm{CFU} \mathrm{g}{ }^{-1}$.

Table 4. Microbial population of sample collected from melon seeds on the market.

\begin{tabular}{|c|c|c|c|c|c|c|}
\hline \multicolumn{2}{|c|}{ Cultivar } & \multirow{2}{*}{$\begin{array}{c}\text { Total aerobic } \\
\text { bacteria }\end{array}$} & \multirow{2}{*}{ E. coli } & \multirow{2}{*}{ Coliform } & \multirow{2}{*}{ B. cereus } & \multirow{2}{*}{ L. monocytogenes } \\
\hline Type & Name & & & & & \\
\hline \multirow{7}{*}{ Net } & & - & - n & $\log \mathrm{CF}$ & - & --------------------- \\
\hline & Superseji & $1.56 \pm 0.24 \mathrm{ef}^{\dagger}$ & N.D..$^{\ddagger}$ & N.D. & N.D. & N.D. \\
\hline & Monered907 & $2.59 \pm 0.05 \mathrm{bcd}$ & N.D. & N.D. & N.D. & N.D. \\
\hline & Eolsdaebak & $3.13 \pm 0.05 \mathrm{ab}$ & N.D. & N.D. & N.D. & N.D. \\
\hline & SSonata & $2.07 \pm 0.10 \mathrm{de}$ & N.D. & N.D. & N.D. & N.D. \\
\hline & Eolsimpact & $1.59 \pm 0.11 \mathrm{ef}$ & N.D. & N.D. & N.D. & N.D. \\
\hline & Eolskingseuta & $2.37 \pm 0.01 \mathrm{~cd}$ & N.D. & N.D. & N.D. & N.D. \\
\hline \multirow{6}{*}{$\begin{array}{l}\text { Non- } \\
\text { net }\end{array}$} & Asia hwanggeum & $0.33 \pm 0.58 \mathrm{~g}$ & N.D. & N.D. & N.D. & N.D. \\
\hline & Sweet home & $1.05 \pm 0.95 \mathrm{f}$ & N.D. & N.D. & N.D. & N.D. \\
\hline & Baggeum melon & $3.34 \pm 0.03 \mathrm{a}$ & N.D. & N.D. & N.D. & N.D. \\
\hline & Numberone & $2.21 \pm 0.04 \mathrm{~d}$ & N.D. & N.D. & N.D. & N.D. \\
\hline & Horunstar & $2.87 \pm 0.04 \mathrm{abc}$ & N.D. & N.D. & N.D. & N.D. \\
\hline & Manruhomrun & $2.67 \pm 0.03 \mathrm{bcd}$ & N.D. & N.D. & N.D. & N.D. \\
\hline
\end{tabular}

${ }^{\dagger}$ values with different letters within the same column differ significantly $(P<0.05)$. Mean \pm Standard Deviation.

${ }^{\ddagger}$ N.D. : Viable cell was not detected with detection limit at $<1 \log$ CFU $\mathrm{g}^{-1}$.

3.94 4.82 $\log \mathrm{CFU} \mathrm{g}^{-1}$ 로 비교적 낮게 검출되었으며 판매 장소에 따라 유의적인 차이는 없었다 $(p<0.05)$. 대장균군은 대형마트와 농산물시장, 재래시장에서 각각 평균 $0.49,0.21$, $0.09 \log \mathrm{CFU} \mathrm{g}^{-1}$ 로 검출되어 $\mathrm{Yu}$ 등 (2009)이 보고한 파프 리카, 딸기와 같은 과채류 평균 오염수준 3.1 5.0 log CFU $\mathrm{g}^{-1}$ 수준 보다 매우 낮은 오염 수준을 보였다. 본 연구에서 대형마트에서 구입한 시료에서 대장균군이 최고 $2.6 \mathrm{log}$ $\mathrm{CFU} \mathrm{g}{ }^{-1}$ 으로 검출되었으나 18 개 시료 중 4 개의 시료에서만 검출되어 평균 오염율이 낮게 조사되었다. Penteado와 Leitao (2004) 은 멜론과 수박 과육에 L. monocytogenes를 $2 \mathrm{log}$ $\mathrm{CFU} \mathrm{g}{ }^{-1}$ 수준으로 접종한 후 $10 \sim 30^{\circ} \mathrm{C}$ 온도 조건에서 생존 및 증식 정도를 조사한 결과 2일 후에 $9 \log \mathrm{CFU} \mathrm{g}^{-1}, 7 \mathrm{log}$ $\mathrm{CFU} \mathrm{g}^{-1}$ 수준으로 증가하는 것을 확인하였다. 멜론은 과실 을 수확하여 후숙을 시킬 경우 당도와 맛이 증가하는 특성 을 가지고 있어, 수확 후 저장고에서 일정기간 후숙 후 유통 이 되고 있는 실정이다 (Kim et al., 2011a). L. monocytogens 균이 멜론에 오염될 경우 $5^{\circ} \mathrm{C}$ 저온에서도 생육이 가능하므 로 식중독 위험성이 높다. Ukuku (2006)는 멜론표면에서
Salmonella spp.를 인위적으로 접종했을 때 세척을 해도 병 원균이 완전히 제거되지 않아 병원균이 멜론표면에 오염될 경우 식중독 발생 위험성이 높다고 하였다. 2011년 미국에 서 멜론에 오염된 리스테리아로 인한 식중독 사고로 콜로라 도를 포함한 28 개주에서 147 명의 환자가 발생하였고, 33 명 의 사망자가 보고되었다 (CDC, 2011). 국내에서 유통되는 멜론에서 B. cereus 등 다른 병원성 미생물은 검출되지 않 아 미생물 오염측면에서 안전하다고 판단된다. 하지만, 멜 론을 포함한 농산물에서 병원성 미생물에 의한 식중독 사고 가 증가하고 있으므로 $(\mathrm{FAO} / \mathrm{WHO}, 2008)$, 국내 농산물에 대한 미생물 안전성을 확보하기 위하여 병원성 미생물의 관 리기준 및 위생안전관리 수립을 위한 연구가 확대 되어야 할 것으로 생각된다.

종자에서 미생물 오염정도 멜론 종자의 미생물 오염 도는 Table 4에 나타낸 바와 같이 총호기성균을 제외하고는 모든 병원성 미생물이 검출되지 않았다. 멜론종자에서 총호 기성균은 네트유무에 따라 유의적인 차이가 확인되지 않았 
으며 $(p<0.05)$, 조사한 시료 중 아시아황금 종자에서 0.33 $\log \mathrm{CFU} \mathrm{g}{ }^{-1}$ 로 가장 낮은 오염도를 보였으며 얼스대박 종 자에서 $3.13 \log \mathrm{CFU} \mathrm{g}^{-1}$ 로 가장 높은 오염도를 보였다. 알 파파 종자에서 E. colio157:H7과 Salmonalla spp. 이 검출되었 고 콩과 겨자종자 등에서 B. creus가 검출 된 바 있다 (Portnoy et al., 1976). 또한, Taormina 등 (1999)은 새싹 종자에 $B$. cereus가 오염되어 있을 경우 발아하는 동안에 $7 \log \mathrm{CFU}$ $\mathrm{g}^{-1}$ 수준까지 증식한다고 보고하였다. 영국에서 건조종자의 병원성 미생물 오염도를 조사한 결과, 참깨종자, 해바라기, 알파파 및 멜론 종자 등에서 Salmonella spp. 와 E. coli 의 오염을 확인 하였다 (Elviss et al., 2013). 국내에서 Yun 등 (2011)은 무와 배추 종자에서 B. cereus가 각각 1.69 와 2.5 $\log \mathrm{CFU} \mathrm{g}^{-1}$ 수준으로 오염되어 있는 것을 확인하였다. 국 내에서 재배되는 멜론종자에서 병원성 미생물이 확인되지 않았지만, 멜론종자 채종과정 중에서 병원성 미생물에 노출 될 가능성이 존재하므로 (Bankole et al., 2005), 채종과정 중 병원성미생물에 오염되지 않도록 주의해야 한다. 종자가 발아하면서 병원성미생물에 오염된 토양, 비료 나 관개수, 분변 등에 노출될 경우 재배과정 중 잠재적인 오염원으로서 작용할 수 있다 (Werner et al., 2007; Winthrop et al., 2003). 열처리나 종자소독 등을 이용할 경우 미생물을 효과 적으로 제어 할 수 있으므로 (Park et al., 2009; Yun et al., 2011), 국내에서도 종자의 미생물 저감화 연구가 보완 되어야 할 것으로 생각된다.

\footnotetext{
Abstract

재배단계와 유통단계에서 멜론의 미생물 위해요소를 조 사하기 위하여 전북 익산과 충남 논산에 위치한 멜론 재배지 에서 토양과 관개수, 식물체를 채집하였다. 수원시에 위치한 대형마트, 농산물시장, 재래시장으로부터 유통되는 멜론과 시 판종자를 채집하여 위생지표세균 3 종 (총호기성균, Coliform, E. coli)과 병원성 미생물 4종 (B. cereus, L. monocytogenes, Salmonella spp., $S$, aureus)을 분석하였다.

멜론 재배과정 중 총호기성균과 대장균군은 각각 0.43 6.65, 0.67 2.91 log CFU g ${ }^{-1}$ 수준으로 검출되었다. Bacillus cereus 는 익산지역의 토양과 멜론 잎에서 각각 $2.95,0.73 \log \mathrm{CFU}$ $\mathrm{g}^{-1}$ 으로 검출되었고, 논산지역의 토양에서 $3.16 \log \mathrm{CFU} \mathrm{g}^{-1}$ 로 검출되었다. 농산물시장, 대형마트, 전통시장에서 멜론의 총호기성균은 각각 4.82, 3.94와 $3.99 \mathrm{log} \mathrm{CFU} \mathrm{g}^{-1}$ 로 확인 되었다. 유통중인 멜론에서 대장균군은 0.09 0.49 log CFU $\mathrm{g}^{-1}$ 범위였으며, 판매장소에 따라 총호기성균과 대장균군 수 준에 유의적인 차이가 나지 않았다. 모든 시료에서 Listeria monocytognes, Salmonells spp., Staphylococcus aureus는 검출되지 않았다. 멜론 종자의 총호기성균은 0.33 3.34 log $\mathrm{CFU} \mathrm{g}{ }^{-1}$ 수준이었다. 관개수, 토양, 가축분뇨와 수확후 처
}

리를 포함한 다양한 농업 활동이 미생물오염의 잠재적인 원 인이기 때문에 토양, 물 과 농자재에 대한 위생관리와 모니 터링이 안전한 멜론 생산을 위하여 수행되어야 할 것으로 생각된다.

\section{References}

Aznar, R. and B. Alarcon. 2003. PCR detection of Listeria monocytogenes: a study of multiple factors affecting sensitivity. J. Appl. Microbiol. 95:953-966.

Bae, Y.M., Y.J. Hong, D.H. Kang, S.G. Heu, and S.Y. Lee. 2011. Microbial and pathogenic contamination of ready to eat fresh vegetables in Korea. Korean J. Food Sci. Technol. 43:161-168. Bankole, S., A. Osho, A. Joda, and O. Enikuomehin. 2005. Effect of drying method on the quality and storability of 'egusi' melon seeds. African J. Biotech. 4:799-803.

Centers for Disease Control and Prevention (CDC). 2008. Surveillance for foodborne disease outbreaks-Unitied States. Morb. Mortal Wkly Rep 60:1197-1202.

Centers for Disease Control and Prevention (CDC). 2011. Multistate outbreak of listeriosis associated with jensen Farms cantaloupeUnited States. August-September. Morb. Mortal Wkly Rep. 60:1357-1358.

Centers for Disease Control and Prevention (CDC). 2013. Surveillance for foodborne disease outbreaks United States 1998-2008. Morb. Mortal Wkly Rep. 62. SS2.

Cha, H.S., S.A. Lee, K.H. Kwon, B.S. Kim, D.J. Choi, and A.R. Youn. 2013. Effects of the Initial storage temperature of a PA film-packaged musk melon (Cucumis melo L.) during its storage. Korean J. Food Preserv. 20:14-22.

Cha, J.H., B.H. Hwang, E.J. Lee, G.P. Lee, and J.K. Kim. 2006. Effect of 1-methylcyclopropene treatment on quality and ethylene production of muskmelon (Cucumis melo L. cv. Reticulatus) fruit. Kor. J. Hort. Sci. Tchnol. 24:452-458.

Choi, H. K., S. M. Park, and C. S. Jeong. 2001. Comparison of quality changes in soil and hydroponic cultured muskmelon fruits. J. Korean Soc. Hort. Sci. 42:264-270.

Choo, E.Y., S.S. Jang, K.S. Kim, K.G. Lee, S.G. Heu, and S.R. Ryu. 2007. Prevlence and genetic diversity of Bacillus cereus in dried red pepper in Korea. J. Food Prot. 70:917-922.

FAO/WHO. 2008. Microbiological hazards in fresh leafy vegetables and herbs : Meeting report. Microbiological Risk Assessment Series 14. FAO/WHO. Rome.

FDA. 2009. Guidance for industry: Guide to minimize microbial food safety hazards of melons. draft guidance. CFSAN. update version 8/24/2011. http://fda.gov/food/guidancecompliancere gulatoryinformation/guidancedocuments/produceandplanpro ducts/ucm174171.htm/

Gagliardi, J.V., P.D. Millner, G. Lester, and D. Ingram. 2003. On-farm and postharvest processing sources of bacterial contamination to melon rinds. J Food Prot. 66:82-87. 
Gallegos-Robles, M.A., A. Moraes, G. Alvarez-Oieda, J.A. Osuna-Garcia, I.O. Martinez, L.H. Morales-Ramos, and P. Fratamico. 2009. PCR detection and microbiological isolation of Salmonella spp. from fresh beef and cantaloupes. J. Fd. Sci. 74:M37-40.

Halverson, L.J., M.K. Clayton, and J. Handelsman. 1993. Population biology of Bacillus cereus UW85 in the rhizosphere of field-grown soybeans. Soil Biol. Biochem. 25:485-493.

Hong, S.J. 2009. Harvest and postharvest technology. In: Manual of postharvest technology of melon. Ministry of for Food Agriculture Foresty and Fisheries and Nonghyup. Seoul. Korea.

Hong, C.K., Y.H. Seo, C.M. Choi, I.S. Hwang, and M.S. Kim. 2012. Microbial quality of fresh vegetables and fruits in Seoul, Korea. J. Fd. Hyg. Safety. 27:24-27.

Elviss, N.C., C.L. Little, L. Hucklesby, S. Sagoo, S.S. Lee, E. Pinna, and E.J. Threlfall. 2013. LACORS/HPA co ordinated food liaison group studies : microbiological aseessment of fresh herbs from retail premises in the united kingdom uncovers an international outreak of salmonellosis. pp21.

Jensen, G.B., B.M. Hansen, J. Eilenberg, and J. Mahillon. 2003. The hidden lifestyles of Bacillus cereus and relatives. Environ. Microbiol. 5:631-640.

Jung, K.S., E.J. Roh, K.Y. Ryu, W.I. Kim, K.H. Park, D.H. Lee, K.H. Kim, J.C. Yun, and S.G. Hur. 2012. Monitoring of pathogenic bacteria in organic vegetables form Korean market. Korean J. Soil Sci. Fert. 45:560-564.

Jung, S.H., M.J. Hur, J.H. Ju, K.A. Kim, S.S. Oh, J.M. Go, Y.H. Kim, and J.S. Im. 2006. Microbiological evaluation of raw vegetables. J. Fd Hyg. Safety. 21:250-257.

Kang, S.T. and J.Y. Yoon. 2004. Foodmicrobiology. hyunseul press. pp. 414-430.

Kerje, T. and M. Grum. 2000. The origin of melon, Cucumis melo: A review of the literature. Acta Hort. 510:37-44.

KFDA. 2011. Food Standard Code. Korea Food and Drug Administration, Seoul, Korea.

Kim, J.Y., K.H. Kwon, K.H. Gu, and B.S. Kim. 2011a. Selection of quality indicator to determine the freshness of muskmelon (Cucumis melo L.) during Distribution. Korean J. Food Preserv. 18:824-289.

Kim, S.R., J.Y. Lee, S.H. Lee, W.I. Kim, K.H. Park, H.J. Yun, B.S. Kim, D.H. Chung, Y.C. Yun, and K.Y. Ryu. 2011b. Evaluation of microbiological safety of lettuce and cultivation area. J. Fd. Hyg. Safety. 6:289-295.

Kong, R.Y., S.K. Lee, T.W. Law, S.H. Law, and R.S. Wu. 2002. Rapid detection of six types of bacterial pathogens in marine waters by multiples PCR. Water Res. 36:2802-2812.

Lee, S.H. 2005. Melon cultivation. Rural development administration. suwon. Korea.

Oh, S.H., R. Bae, and S.K. Lee. 2011. Current status of research on the postharvest technology of melon (Cucumis melo L.). Krean J Food Preserv. 18:442-458.
Painter, J.A., R.M. Hoekstra, T. Ayers, R.V. Tauxe, C.R. Braden, F.J. Angulo, and P.M. Griffin. 2013. Attribution of foodborne illnesses, hospitalizations, and deaths to food commodities by using outbreak data, United States, 1998-2008. Emerg Infect Dis. 19:407-145.

Park, E.J., J.H. Kwon, and Y.K. Lee. 2009. Germination rate and microbial safety during cultivation of disinfected seeds. Korean J. Food Preserv. 16:292-298.

Park, K. H, B. S. Kim, J. J. Lee, H. J. Yun, S. R. Kim, W. I. Kim, J. C. Yun, and K. Y. Ryu. 2012. Biological hazard analysis of Angelica gigas Nakai on production and marketing steps. Korean J. Soil. Sci. Fert. 45:1216-1221.

Penteado, A. L. and M. F. F. Leitao. 2004. Growth of Listeria monocytogenes in melon, watermelon and papaya pulps. Food Microbiol. 92:89-94.

Pitrat, M., P. Hanelt, and K. Hammer. 2000. Some comments on infraspecific classification of cultivars of melon. Acta Hort. 510:29-36.

Portnoy B.L, J.M. Gtoepfert, and S.M. Harmon. 1976. An outbreak of Bacillus cereus food poisoning resulting from contaminated vegetable sprouts. Am. J Epidemiol. 103:589-594.

Suslow, T., A. Sbodio, G. Lopez, P. Wei, and K.H. Tan. 2010. Melon food safety: 2010 Final Report. California Melon Research Board. http://www.cmrb.org/documents/files/201101 100859 01.pdf.

Taormina P.J., L.R. Beuchat, and L. Slutskert. 1999. Infection associated with eating seed sprouts. J. Emerg. Infect. Dis. 5:6266-634.

Ukuku, D.O. 2006. Effect of sanitizing treatments on removal of bacteria from cantaloupe surface and re-contamination with Salmonella. Fd. Mcirobial. 23:289-293.

Ukuku, D.O., M. Olanya, D.J. Geveke, and C.H. Sommers. 2012. Effective of native microflora, waiting period, and storage temperature on Listeria monocytogenes serovars transferred from cantaloupe rind to fresh-cut pieces during preparation. J. Food Prot. 75:1912-1919.

Werner, S., K. Boman, I. Einemo, M. Erntell, R. Helisola, B. de Jong, A. Lindqvist, S. Lofdahl, A. Meeuwisse, G. Ohlen, M. Olsson, I. Persson, A. Runehagen, G. Rydevik, U. Stamer, E. Sellstrom, and Y. Andersson. 2007. Outbreak of Salmonella stanley in Sweden associated with alfalfa sprouts, July-August 2007. Eurosurveillance 12:3291.

Winthrop, K.L., M.S. Palumbo, J.A. Farrar, J.C. Mohle-Boetani, S. Abbott, M.E. Beatty, G. Inami, and S.B. Werner. 2003. Alfalfa sprouts and disinfection with heat and chlorine. J Food Prot. 66:13-17.

Vicedo, A.B. and R. Aznar. 2006. PCR based procedures for the detection and quantification of Staphylococcus aureus and their application in food. J. Appl. Microbiology. 100: 353-364.

Yi, S.I., Y.S. Kwon, K.M. Bae, and J.H. Song. 2004. Recent progress for the variety classification and denomination of oriental melon and melon (Cucumis melo L.). Kor J Hort Sci 
Technol. 22:515-522.

Yong, S.S. 2008. Food value of muskmelon. RDA. Suwon. Korea.

Yu, Y.M., Y.N. Youn, Q.J. Hua, G.H. Cha, and Y.H. Lee. 2009. Biological hazard analysis of paprikas, strawberries and tomatoes in the markets. J. Fd Hyg. Safety. 24:174-181.

Yun, H.J., K.H. Park, E.K. Hong, T.H. Kim, S.R. Kim, W.I. Kim,
J.C. Yun, and K.Y. Ryu. 2011. Effects of improved heat treatment on microbial reduction and germination in sprout vegetable seeds. Korean J. Food Sci. Technol. 43:611-617.

Zhang, C.H, H.M. Kang, and I.S. Kim. 2006. Effect of using waste nutrient solution fertigation on the musk melon and cucumber growth. J. Bio-Env. Cont. 15:400-405. 